УдК 330.59:316.346.32-053.9

\title{
РЕАЛИЗАЦИЯ ПОТЕНЦИАЛА СТАРШЕГО ПОКОЛЕНИЯ. УРОВЕНЬ ЖИЗНИ
}

\author{
Касинский Сергей Викторович1, \\ P70_mail@gks.ru \\ Дырко Нина Петровна', \\ P70_mail@gks.ru \\ Котова Валентина Викторовна1, \\ P70_mail@gks.ru \\ Павлова Ирина Анатольевна ${ }^{2,3,4}$, \\ iapav@mail.ru \\ Гуменников Илья Владимирович3, \\ gumennikov@tpu.ru

\section{Монастырный Евгений Александрович3,4,2,} \\ e.monastyrny@gmail.com
}
1 Территориальный орган Федеральной службы государственной статистики по Томской области, Россия, 634050, г. Томск, ул. Гагарина, 56.
2 Томский научный центр СО РАН, Россия, 634055, г. Томск, пр. Академический, 10/4.

${ }^{3}$ Национальный исследовательский Томский политехнический университет, Россия, 634050, г. Томск, пр. Ленина, 30.

4 Томский государственный университет систем управления и радиоэлектроники, Россия, г. Томск, пр. Ленина, 40. E-mail: iapav@mail.ru.

Касинский Сергей Викторович, руководитель Территориального органа Федеральной службы государственной статистики по Томской области.

Дырко Нина Петровна, заместитель руководителя Территориального органа Федеральной службы государственной статистики по Томской области.

Котова Валентина Викторовна, главный специалист-эксперт отдела сводных статистических работ Территориального органа Федеральной службы государственной статистики по Томской области.

Павлова Ирина Анатольевна, кандидат экономических наук, старший научный сотрудник лаборатории устойчивого развития социально-экономических систем Томского научного центра СО PAН; доцент Школы инженерного предпринимательства Национального исследовательского Томского политехнического университета; доцент кафедры управления инновациями Томского государственного университета систем управления и радиоэлектроники.

Гуменников Илья Владимирович, программист Отдела портальных решений Национального исследовательского Томского политехнического университета.

Монастырный Евгений Александрович, доктор экономических наук, профессор Школы инженерного предпринимательства Национального исследовательского Томского политехнического университета; профессор кафедры управления инновациями Томского государственного университета систем управления и радиоэлектроники; заведующий лабораторией устойчивого развития социально-экономических систем Томского научного центра СО РАН. 
В современном мире меняются основные показатели социально-экономического развития общества. Значимость социологических опросов растет, придавая больший вес субъективным оценкам процессов, проходящих в обществе. Показатель ВВП на душу населения, который долгие десятилетия являлся главной интегральной оценкой общественного прогресса, уступает место комплексным показателям качества жизни и благополучия населения. Такие индикаторы используются для изучения и оценки сложно структурированных явлений. В последнее время научное сообщество пытается предложить инструмент для оценки качества жизни и благополучия людей. Постепенно складывается мнение, что этот инструмент должен содержать как объективные данные, описывающие изучаемое явление, так и субъективные измерители, предназначенные для учета субъективного отношения людей. В то же время происходит процесс сокращения доли трудоспособного населения и увеличения числа пожилых людей. Поэтому в данном исследовании сосредоточено внимание на людях, достигших пенсионного возраста. В работе проводится сопоставление статистических данных и данных социологических опросов для оценки качества жизни пожилых людей в Томской области. Источниками информации стали аналитическая записка «Старшее поколение Томской области: демография и участие на рынке труда», опубликованная Томскстатом в 2019 г., и социологический опрос «Проблемы людей старшего поколения», проведенный в Международной научно-образовательной лаборатории технологии улучшения благополучия пожилых людей ТПУ в 2019 г. Результаты показывают, что исходя из статистических данных качество жизни пенсионеров за последние несколько лет не изменилось или немного улучшилось, в то время как по социологическим данным оно осталось на прежнем уровне или несколько ухудшилось.

Ключевые слова: Качество жизни, благополучие, пожилые люди, объективные показатели, субъективные оценки, Томская область.

Качество жизни является одним из главных индикаторов благополучия социальных групп и общества в целом. Международная научно-образовательная лаборатория технологии улучшения благополучия пожилых людей (МНОЛ ТУБПЛ) Томского политехнического университета с 2014 г. проводит оценку положения граждан старшего поколения. Помимо регулярных социологических опросов и анализа статистической информации для определения уровня жизни в этой социальной группе разработан Российский индекс благополучия старшего поколения (РИБСП) [1], который дает интегральную оценку благополучия людей $[2,3]$, перешедших границу пенсионного возраста. Методология этого инструмента предполагает совместное использование объективных и субъективных показателей для получения более полной, приближенной к реальности оценки $[4,5]$. В настоящей работе предпринята попытка описания некоторых компонентов качества жизни с помощью их рассмотрения как с точки зрения официальной статистики, так и с точки зрения оценочных суждений. В статье рассматривается главным образом материальная сторона. Информационной базой для подобного описания стали данные серии аналитических записок [6], подготовленных совместно с Территориальным органом Федеральной службы государственной статистики по Томской области, и социологического опроса «Проблемы людей старшего поколения», проведенного МНОЛ ТУБПЛ в 2019 г. Выборка составила 450 человек в возрасте от 50 лет и старше, проживающих в г. Томске и Томской области.

За последнее десятилетие индекс самооценки материального положения россиян [7], рассчитываемый ВЦИОМ, несколько раз менял свое направление. До 2008 г. наблюдалась устойчивая положительная динамика, с наступлением кризисного периода в 2008 г. доля людей, заявляющих об ухудшении материального положения, начала расти. Тем не менее до 2014 г. индекс самооценки материального положения демонстрировал устойчивый рост, но с весны 2014 г. наблюдаются первые негативные тренды, перешедшие в резкий спад оценок респондентов. Спад оценок благополучия старшего поколения начиная с 2014 г. был зафиксирован и РИБСП. 
В Томской области, как и в целом по стране, главным источником дохода старшего поколения является пенсия. Так, по данным Всероссийской переписи населения 2010 г. более 60 \% населения старше трудоспособного возраста проживало в первую очередь на пенсию. Вторым основным источником средств к существованию для многих являлось личное подсобное хозяйство, третьим - доход от трудовой деятельности, на которые проживало соответственно 16 и 14 \% лиц старшего возраста.

Данные опроса показывают, что пенсия и пособия являются основным источником доходов для подавляющего большинства опрошенных $(80 \%)$. Значимость этого источника сильно зависит от возраста. В предпенсионный период (до 54 лет) первое место среди источников дохода занимает заработная плата (76 \%). Хотя и в этом возрасте об ориентации на пенсию указал каждый четвертый респондент (27 \%). В возрасте 55-59 лет (который является предпенсионным для мужчин и активным пенсионным - для женщин) зависимость от источников дохода является гендерной. Мужчины чаще указывают зарплату, женщины - пенсию, что в сумме приводит к высокой значимости обоих источников (одновременно можно было выбрать несколько вариантов). Так, на заработную плату ориентируются 56 \% опрошенных в возрасте 54-59 лет, а на пенсию - $74 \%$.

По данным отделения Пенсионного фонда РФ по Томской области на 1 января 2019 г. пенсию по старости получали 260,1 тыс. человек, что на 31,2 тыс. человек больше, чем на начало 2011 г. (см. таблицу).

\section{Таблища. Основные показатели обеспечения пенсионеров, получающих пенсии по старости}

Table. Main indicators of provision of pensioners receiving old-age pensions

\begin{tabular}{|c|c|c|c|c|c|}
\hline Показатели/Indicators & 2010 & 2015 & 2016 & 2017 & 2018 \\
\hline $\begin{array}{l}\text { Численность пенсионеров, состоящих на учете в системе } \\
\text { Пенсионного фонда Томской области }{ }^{1} \text {, тыс. чел. } \\
\text { The number of pensioners registered in the Pension Fund of } \\
\text { Tomsk Region }{ }^{1)} \text { thousand people }\end{array}$ & 228,9 & 251,4 & 254,9 & 257,3 & 260,1 \\
\hline из них работающих/including the working pensioners & 95,7 & 119,5 & 67,3 & 65,4 & 65,3 \\
\hline $\begin{array}{l}\text { Средний размер назначенных пенсий }{ }^{1)}, \mathrm{p} \text {. } \\
\text { Average amount of assigned pensions }{ }^{1)}, \text { rubles }\end{array}$ & 8832 & 13875 & 14241 & 15271 & 16133 \\
\hline $\begin{array}{l}\text { Реальный размер назначенных месячных пенсий, \%, к преды- } \\
\text { дущему году } \\
\text { The actual amount of the assigned monthly pensions, in \% to the } \\
\text { previous year }\end{array}$ & 112,7 & 101,9 & 97,6 & 104,7 & 100,2 \\
\hline $\begin{array}{l}\text { Величина прожиточного минимума пенсионера, p. } \\
\text { The value of the living wage of a pensioner, rubles }\end{array}$ & 4766 & 8470 & 8557 & 8604 & 8718 \\
\hline $\begin{array}{l}\text { Соотношение среднего размера назначенных месячных пен- } \\
\text { сий, процентов } \\
\text { The ratio of the average amount of the assigned monthly pensions, } \\
\text { percent: }\end{array}$ & & & & & \\
\hline $\begin{array}{l}\text { с величиной прожиточного минимума пенсионера } \\
\text { with the cost of living of senior citizen }\end{array}$ & 181,3 & 166,8 & 172,9 & 183,7 & 189,5 \\
\hline $\begin{array}{l}\text { co средним размером начисленной заработной платы } \\
\text { with average payroll }\end{array}$ & 41,6 & 43,6 & 41,7 & 40,3 & 41,6 \\
\hline
\end{tabular}

1) На 1 января года, следующего за отчётным/On January 1 of the year following the reporting year

Средний размер назначенных месячных пенсий по старости на 1 января 2019 г. составил 16133 руб., по сравнению с 1 января 2011 г. он увеличился в номинальном выражении в 1,8 раза, в реальном (с учетом инфляции) - на 7,8 \%. 
С 2010 по 2018 г. дважды наблюдалось снижение реального размера назначенных месячных пенсий по старости в 2014 г. и в 2016 г. (на 5,7 \% и 2,7 \%) (рис. 1). В целом с 2014 г. реальный размер назначенных пенсий незначительно увеличился.

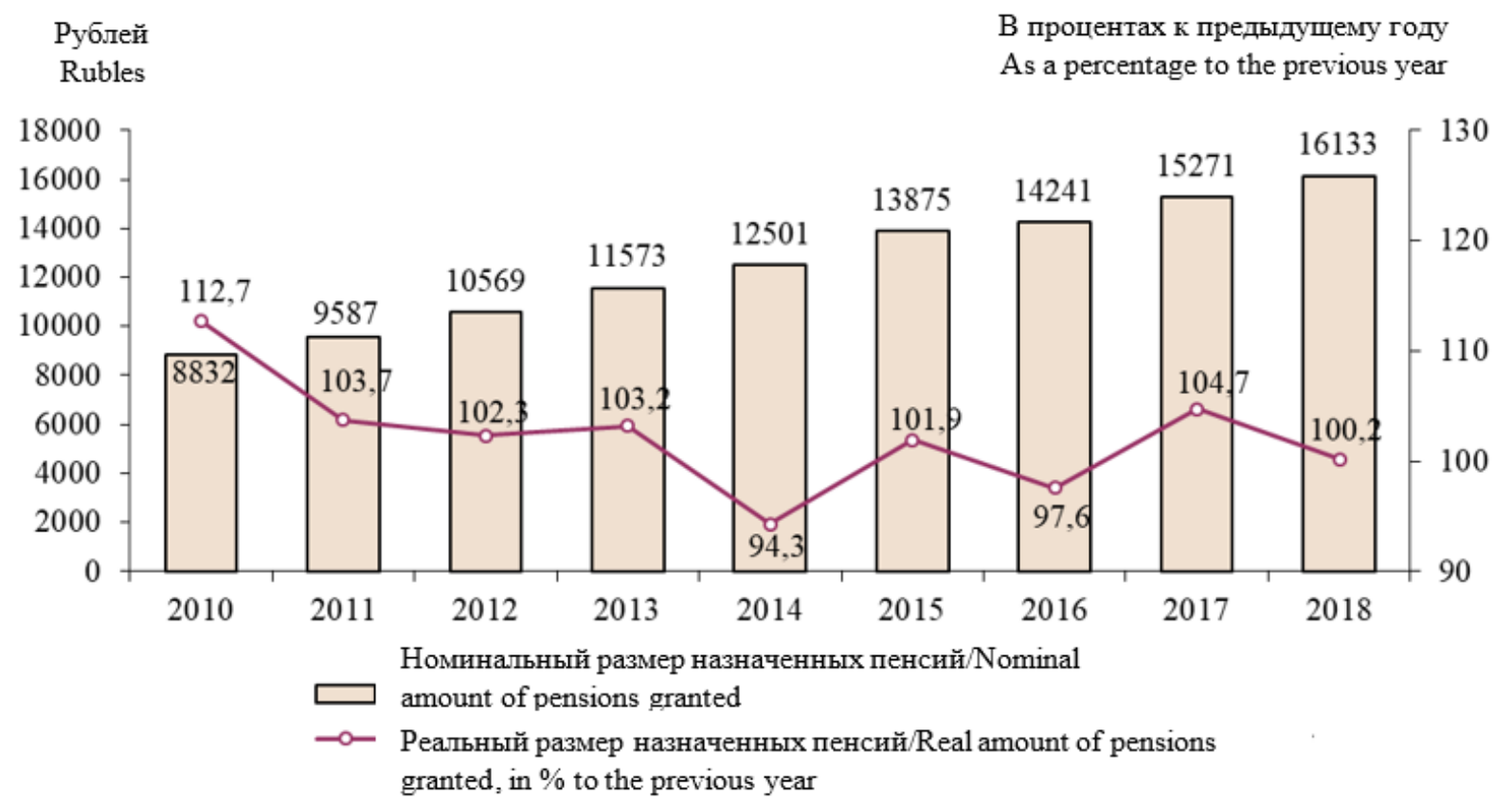

Рис. 1. Динамика номинального и реального размера назначенных месячных пенсий по старости на 1 января года, следующего за отчётным

Fig. 1. Dynamics of the nominal and real size of the assigned monthly old-age pensions as of January 1 of the year following the reporting

Каждый третий опрошенный ответил, что в среднем на одного члена семьи их доход составляет от 13 до 18 тыс. руб. Каждый пятый - от 19 до 25 тыс. В этих доходных группах уровень материального обеспечения сопоставим у мужчин и женщин. Мужчины вдвое чаще отмечали большие суммы (от 26 тыс. руб.), чем женщины, которые, в свою очередь, чаще указывали низкие доходные группы - от 6 до 12 тыс. и ниже 6 тыс. руб. Доход выше 19 тыс. руб. чаще отмечали респонденты предпенсионного возраста (рис. 2). Тем не менее среди тех, кто старше 73 лет, 30 \% также указали, что в среднем в месяц их доход составляет свыше 19 тыс. руб. К самой низкодоходной группе чаще относили себя лица до 54 лет: 13 \% из них ответили, что среднедушевой доход в их семье - менее 6 тыс. руб.

Как показано на рис. 3, более половины из тех, кто указал, что в среднем его доход составляет от 26 до 50 тыс. руб., отметили, что могут покупать многое, но крупные приобретения им не доступны (58 \%). Большинство тех, кто указали диапазоны по доходу 13-18 и 6-12 тыс. руб., в основном отмечали, что все деньги уходят на питание (42-43 \%). В самой малообеспеченной группе (доход ниже 6 тыс.) каждый второй говорил, что денег не хватает даже на питание (52\%).

Уровень жизни пенсионеров существенно ниже, чем у работающего населения. В 2018 г. средний размер пенсии по старости составлял 41,6 \% от средней заработной платы, сложившейся в области. Дифференциация подтверждается и соотношением размера заработной платы и пенсии с величиной прожиточного минимума. В 2018 г. средний размер пенсии по старости в 1,9 раза превышал величину прожиточного ми- 
нимума пенсионера, в то время как заработная плата была в 3,6 раза выше величины прожиточного минимума трудоспособного населения (рис. 4).
$50-54$ года
years
$55-59$ лет
years
- $60-72$ года
- 73 года и старше

무 $1 \%$

Больше 51 тысяч рублей

More than 51 thousand

26-51 тысяч рублей

thousand rubles

19-25 тысяч рублей

thousand rubles

13-18 тысяч рублей

thousand rubles

6-12 тысяч рублей thousand rubles

Меныше 6 тысяч рублей

Less than 6 thousand rubles

Затрудняюсь ответить

Difficult to answer

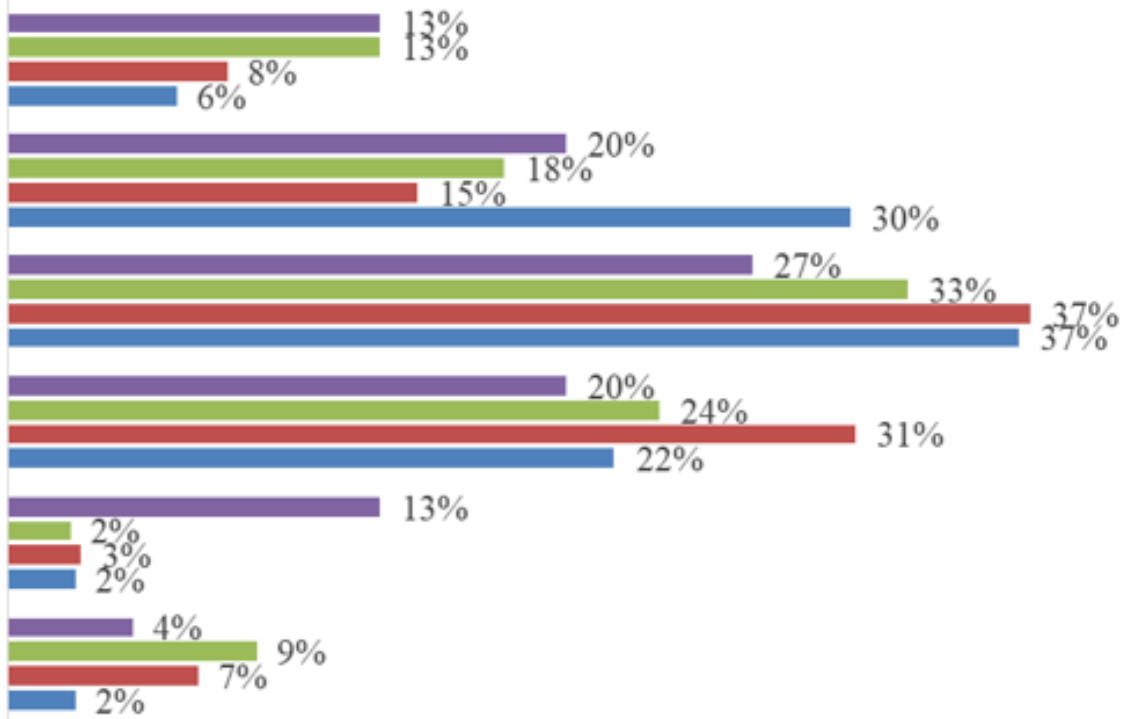

Puc. 2. Самооценка уровня доходов по возрастным группам, \% Fig. 2. Self-assessment of income by age groups, \%

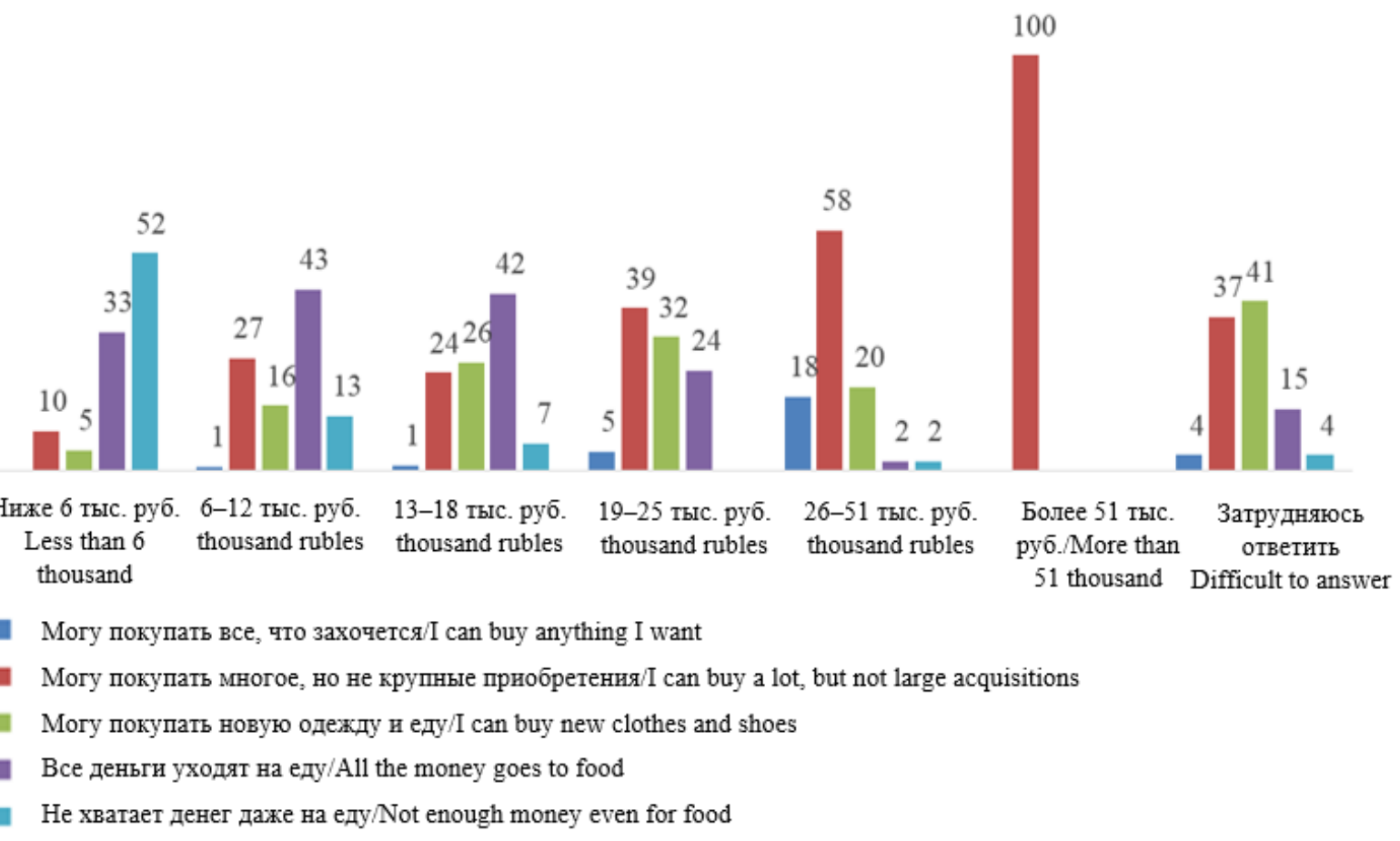

Рис. 3. Самооценка уровня дохода и материального положения, \%

Fig. 3. Self-assessment of income and financial situation, \% 


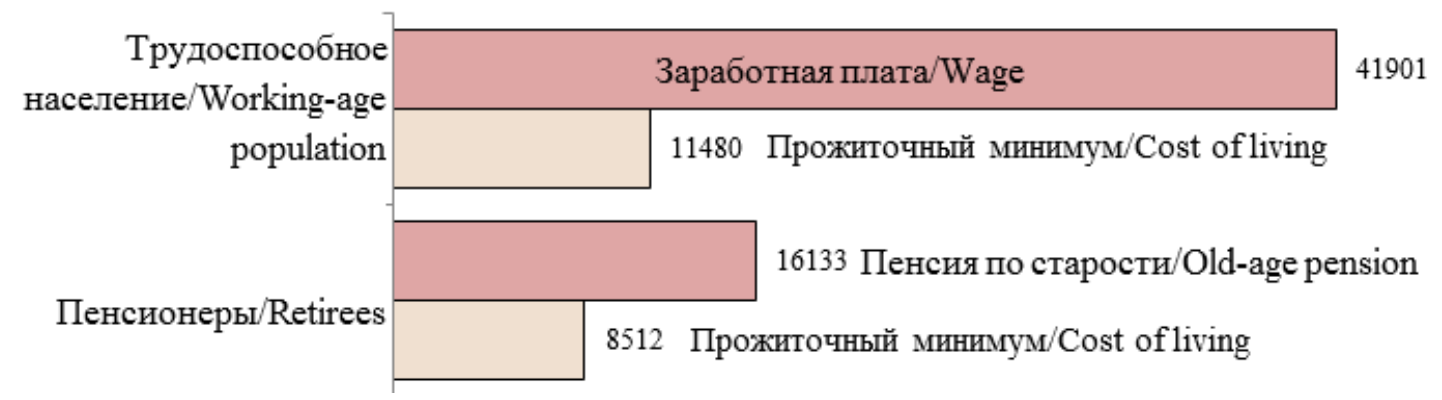

Puc. 4. Основные источники денежных доходов отдельных групп населения и установленная для них величина прожиточного минимума за 2018 г., p/мес.

Fig. 4. Main sources of cash income of certain groups of the population and the amount of the subsistence minimum established for them for 2018, rubles per month

Многие пенсионеры после выхода на пенсию продолжают работать из-за недостатка денежных средств на текущее потребление, желания быть вовлеченными в социум, стремления сформировать сбережения на будущее.

Разницу в качестве жизни между работающими и пенсионерами хорошо отражает самооценка уровня доходов. На рис. 5 видна разница в уровне потребления в зависимости от возраста. В возрасте до 60 лет доля людей, кто может покупать многое, кроме крупных приобретений, выше, чем в старших возрастах. А среди тех, кто тратит все деньги на питание, преобладают люди в возрасте старше 60 лет (рис. 5).

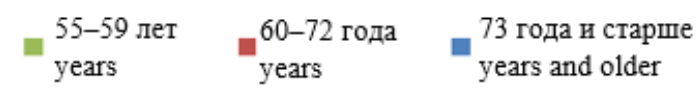

$$
\begin{array}{r|c}
\text { Могу покупать все, что захочется } & 2 \% \\
\text { I can buy anything I want } & 4 \%
\end{array}
$$

Могу покупать многое, но не крупные приобретения I can buy a lot, but not large acquisitions

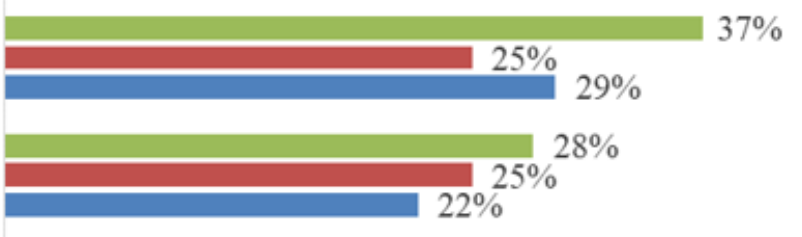

Могу покупать новую одежду и обувь I can buy new clothes and shoes

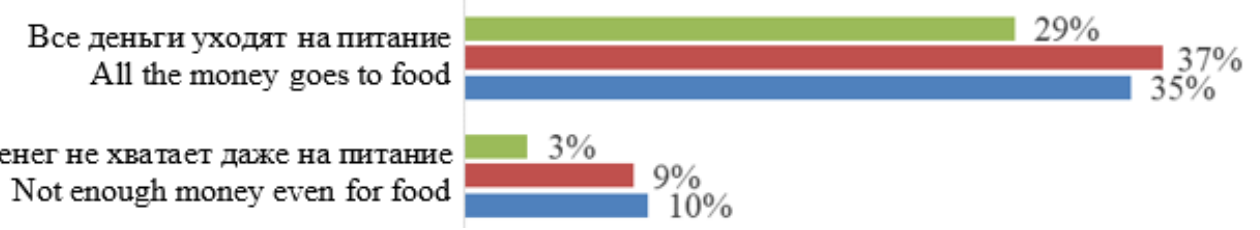

Pис. 5. Самооценка уровня материального положения по возрастным группам, \% Fig. 5. Self-assessment of the level of financial situation by age groups, in \%

В рамках социологического опроса, респондентам задавали вопрос: «Как Вы оцениваете в целом условия Вашей жизни за последние два-три года?» (рис. 6). Самооценка текущего состояния условий жизни скорее нейтральная: 45 \% заявили, что ничего не изменилось. Оставшиеся респонденты чаще указывали на ухудшение ситуации, чем на ее улучшение. Так, на значительное улучшение указали только 3 \% опрошенных, в то время как на ухудшение - $10 \%$.

По полу и возрасту явных тенденций не выявлено, за исключением того, что лица старшего пенсионного возраста чаще указывали на отсутствие каких бы то ни было изменений в их условиях жизни за последние 2-3 года (57 \%). 


$$
\begin{array}{lll}
55-59 \text { лет } & \begin{array}{l}
60-72 \text { года } \\
\text { years }
\end{array} & \begin{array}{l}
73 \text { года и старше } \\
\text { years }
\end{array}
\end{array}
$$

Значительно улучшились

Signific antly improved

Стали лучше, но ненамного

Better, but not by much

Ничего не изменилось Nothing changed
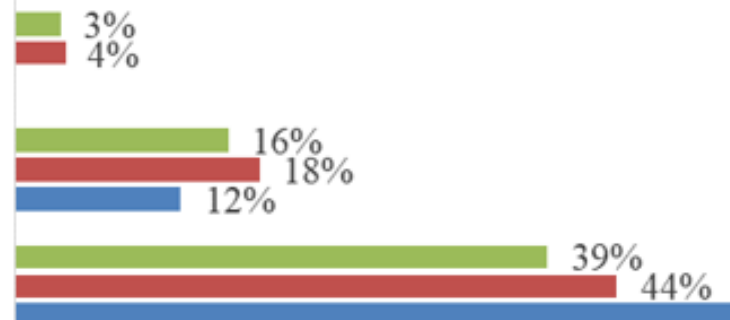

Кое-что стало хуже

Something has changed for the worse
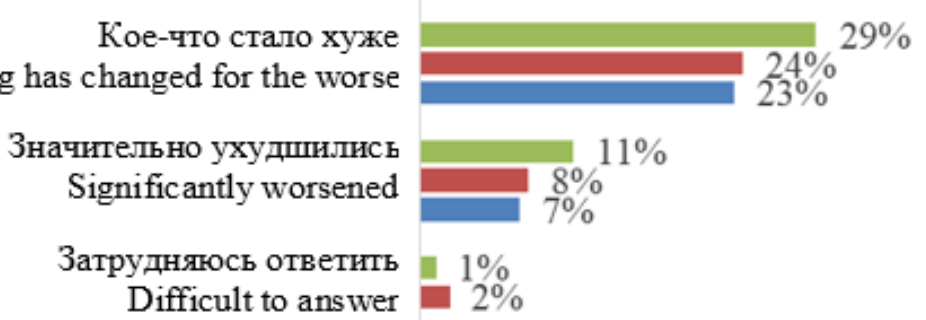

Pис. 6. Оценка условий жизни по возрастным группам, \% Fig. 6. Assessment of living conditions by age groups, in \%

\section{Насколько Вы удовлетворены следующими сторонами Вашей жизни? \\ How satisfied are you with the following aspects}

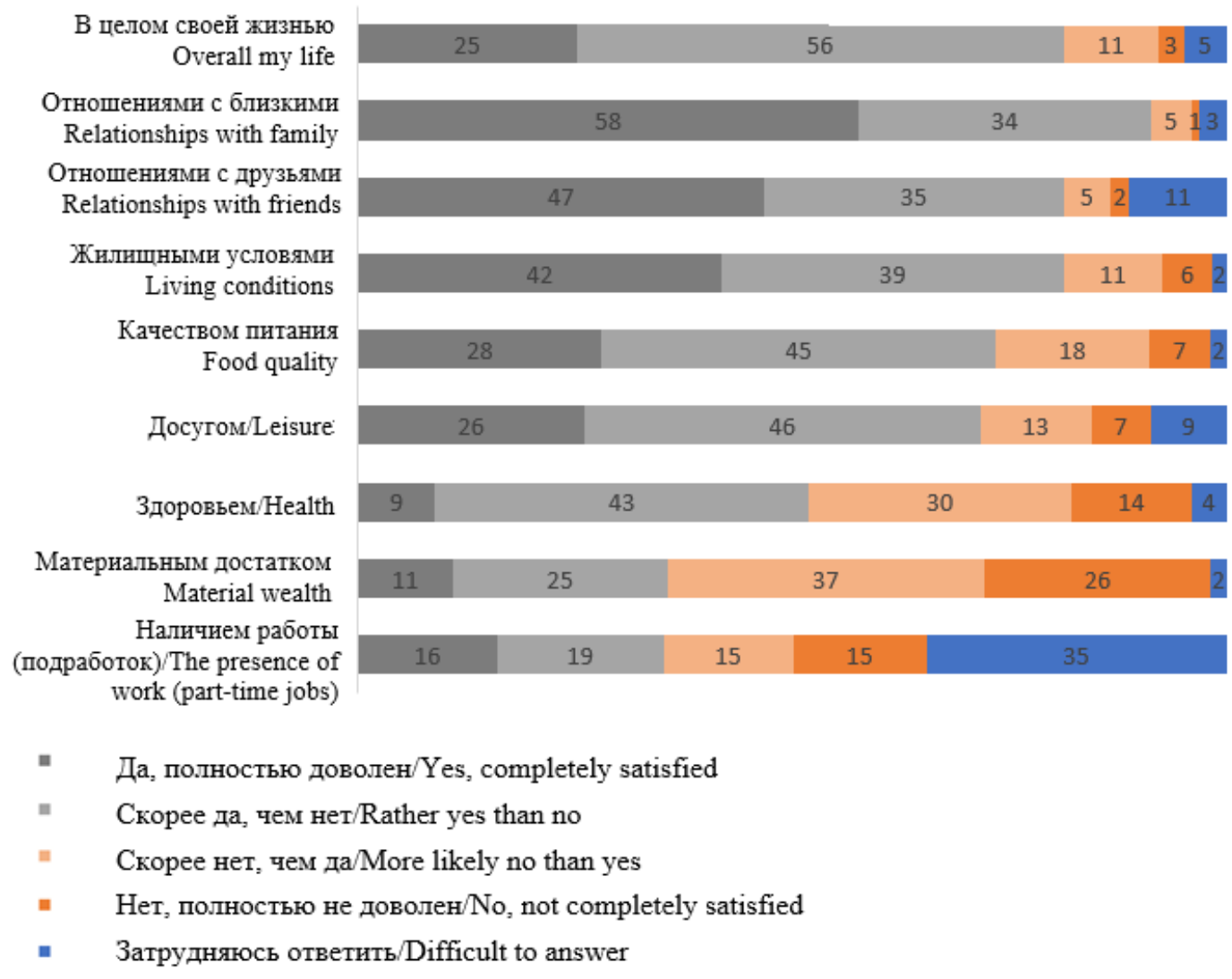

Pис. 7. Уровень удовлетворенности разными сторонами жизни, \% Fig. 7. Level of satisfaction with different aspects of life, \% 
Из сопоставления объективных и субъективных данных для оценки качества жизни пожилых людей в Томской области можно заключить, что при рассмотрении статистических данных качество жизни пенсионеров за последние несколько лет не изменилось или незначительно улучшилось, в то время анализ социологических данных показывает, что оно осталось на прежнем уровне или немного ухудшилось.

Исследование выполнено за счет гранта Российского научного фонда (проект № 19-18-00300) «Институты реализации ресурсного потенциала старшего поколения в экономике старения».

\section{СПИСОК ЛИТЕРАТУРЫ}

1. Российский индекс благополучия старшего поколения: методология, методика, апробация / И.П. Павлова, Е.А. Монастырный, И.В. Гуменников, Г.А. Барышева // Журнал исследований социальной политики. - 2018. - Т. 16. - № 1. - С. 23-36. - URL: https://doi.org/10.17323/727-0634-2018-161-23-36 (дата обращения 17.12.2019)

2. Старшее поколение Томской области: демография и участие на рынке труда: Аналитическая записка. - Томск: Томскстат, 2019. - 18 с.

3. Boarini R., Kolev A., McGregor A. Measuring well-being and progress in countries at different stages of development: towards a more universal conceptual framework // OECD Development Centre Working Papers. - Paris: OECD Publishing, 2014. - P. 8-10.

4. New well-being measures: short scales to assess flourishing and positive and negative feelings / E. Diener, D. Wirtz, W. Tov, C. Kim-Prieto, D.W. Choi, S. Oishi, R. Biswas-Diener // Social Indicators Research. 2010. - V. 97 (2). - P. 143-156.

5. Quality of life: an approach integrating opportunities, human needs, and subjective well-being / R. Costanza, B. Fisher, S. Ali, C. Beer, L. Bond, R. Boumans, D.E. Gayer // Ecological Economics. - 2007. - V. 61 (2). P. 267-276.

6. MacLeod A.K. Well-being: objectivism, subjectivism or sobjectivism? // Journal of Happiness Studies. 2015. - V. 16 (4). - P. 1073-1089.

7. Социальное самочувствие россиян: методика. - 2019. - URL: https://wciom.ru/index.php?id=236\&uid=9746 (дата обращения 18.12.2019).

Поступила 10.01.2020 г. 
UDC 330.59:316.346.32-053.9

\title{
REALIZATION OF THE POTENTIAL OF THE OLDER GENERATION. STANDARD OF LIVING
}

\author{
Sergey V. Kasinsky ${ }^{1}$, \\ P70_mail@gks.ru \\ Nina P. Dyrko1, \\ P70_mail@gks.ru \\ Valentina V. Kotova ${ }^{1}$, \\ P70_mail@gks.ru \\ Irina A. Pavlova ${ }^{2,3,4}$, \\ iapav@mail.ru
}

Ilya V. Gumennikov3, gumennikov@tpu.ru

\author{
Eugeniy A. Monastyrny,3,2, \\ e.monastyrny@gmail.com
}

1 Territorial Body of the Federal Service for State Statistics for the Tomsk Region, 56, Gagarin street, Tomsk, 634050, Russia.

2 Tomsk Scientific Center SB RAS, 10/4, Akademicheskiy avenue, Tomsk, 634055, Russia.

${ }^{3}$ National Research Tomsk Polytechnic University, 30, Lenin avenue, Tomsk, 634050, Russia.

${ }^{4}$ Tomsk State University of Control Systems and Radioelectronics, 40, Lenin avenue, Tomsk, Russia.

Sergey V. Kasinsky, head of the Territorial Body of the Federal Service for State Statistics for the Tomsk Region.

Nina P. Dyrko, deputy head of the Territorial Body of the Federal Service for State Statistics for the Tomsk Region.

Valentina V. Kotova, chief specialist, aggregated statistical efforts department of the Territorial Body of the Federal Service for State Statistics for the Tomsk Region.

Irina A. Pavlova, Cand. Sc., senior researcher, Tomsk Scientific Center SB RAS, 10/4, Akademicheskiy avenue, Tomsk, 634055, Russia; associate professor, National Research Tomsk Polytechnic University; associate professor, Tomsk State University of Control Systems and Radioelectronics.

Ilya V. Gumennikov, programmer, National Research Tomsk Polytechnic University.

Eugeniy A. Monastyrny, Dr. Sc., professor, National Research Tomsk Polytechnic University, 30, Lenin avenue, Tomsk, 634050, Russia; professor, Tomsk State University of Control Systems and Radioelectronics, Russia, Tomsk, 40, Lenin avenue; head of the laboratory of sustainability of socio-economic systems, Tomsk Scientific Center SB RAS.

The basic indicators of socio-economic development of societies are changing in the modern world. The importance of opinion polls is growing, giving more weight to subjective assessments of the processes taking 
place in society. The per capita GDP indicator, which has been the main integral measure of social progress for many decades, gives way to comprehensive indicators of the quality of life and well-being. Such estimates are used to study and evaluate complexly structured phenomena. The scientific community has been trying to offer a tool to assess the quality of life and well-being of people. Currently, we understand that this tool should contain both objective data describing the assessed phenomenon and subjective assessments designed to take into account the subjective attitude of people. At the same time, in modern society there is a process of reducing the share of the working population and increasing the number of older people. Therefore, in this work, we focused on people who have reached retirement age. The paper compares statistical data and sociological survey data to assess the quality of life of older people in the Tomsk region. The analytical note «The senior generation of the Tomsk region: demography and participation in the labor market» published by Tomskstat in 2019, and the sociological poll «Problems of the older generation», conducted at the TPU Lifelong Well-being Lab in 20196 became the sources of information. The results show that, based on statistical data, the quality of life of pensioners over the past few years has not changed or increased slightly, while, based on sociological data, it remained at the same level or slightly decreased.

Key words: Quality of life, well-being, elderly people, objective indicators, subjective assessments, Tomsk region.

The research was carried out of the funds of the grant or the Russian Science Foundation (project no. 19-18-00300) "Institutes of implementation of resource potential of senior generation in the aging economics».

\section{REFERENCES}

1. Pavlova I.A., Monastyrny E.A., Gumennikov I.V., Barysheva G.A. The Russian Elderly Well-being Index (REWI): methodology, methods, approbation. The Journal of social policy studies, 2018, vol. 16, no. 1, pp. 23-36. In Rus. Available at: https://doi.org/10.17323/727-0634-2018-16-1-23-36 (accessed 17 December 2019).

2. Starshee pokolenie Tomskoy oblasti: demografiya i uchastie na rynke truda: analiticheskaya zapiska [The older generation of the Tomsk region: demography and participation in the labor market: An analytical note]. Tomsk, Tomskstat Publ., 2019. 18 p.

3. Boarini R., Kolev A., McGregor A. Measuring Well-Being and Progress in Countries at Different Stages of Development: Towards a More Universal Conceptual Framework. OECD Development Centre Working Papers. Paris, OECD Publishing, 2014. pp. 8-10.

4. Diener E., Wirtz D., Tov W., Kim-Prieto C., Choi D. W., Oishi S., Biswas-Diener R. New well-being measures: short scales to assess flourishing and positive and negative feelings. Social Indicators Research, 2010, vol. 97 (2), pp. 143-156.

5. Costanza R., Fisher B., Ali S., Beer C., Bond L., Boumans R., Gayer D. E. Quality of life: an approach integrating opportunities, human needs, and subjective well-being. Ecological Economics, 2007, vol. 61 (2), pp. 267-276.

6. MacLeod A.K. Well-being: objectivism, subjectivism or sobjectivism? Journal of Happiness Studies, 2015, vol. 16 (4), pp. 1073-1089.

7. Sotsialnoe samochuvstvie rossiyan: metodika [Social feeling of the Russians: methodology]. 2019. Available at: https://wciom.ru/index.php?id=236\&uid=9746 (accessed 18 December 2019).

Received: 10 January 2020. 